\title{
Visible-light-responsive $\mathrm{ZnCuO}$ nanoparticles: benign photodynamic killers of infectious protozoans
}

\author{
Akhtar Nadhman ${ }^{1,2}$ \\ Samina Nazir ${ }^{2}$ \\ Malik Ihsanullah Khan' \\ Attiya Ayub 2,3 \\ Bakhtiar Muhammad ${ }^{3}$ \\ Momin Khan' \\ Dilawar Farhan Shams ${ }^{4}$ \\ Masoom Yasinzai ${ }^{1,5}$ \\ 'Department of Biotechnology, \\ Quaid-i-Azam University, Islamabad, \\ Pakistan; ${ }^{2}$ Nanosciences and Catalysis \\ Division, National Centre for Physics, \\ Quaid-i-Azam University Campus, \\ Islamabad, Pakistan; ${ }^{3}$ Department \\ of Chemistry, Hazara University, \\ Dhodial, Pakistan; ${ }^{4}$ Department of \\ Environmental Sciences, Abdul Wali \\ Khan University Mardan, Mardan, \\ Pakistan; ${ }^{5}$ Center of Interdisciplinary \\ Research, International Islamic \\ University, Islamabad, Pakistan
}

This article was published in the following Dove Press journal:

International Journal of Nanomedicine

4 November 2015

Number of times this article has been viewed

\begin{abstract}
Human beings suffer from several infectious agents such as viruses, bacteria, and protozoans. Recently, there has been a great interest in developing biocompatible nanostructures to deal with infectious agents. This study investigated benign $\mathrm{ZnCuO}$ nanostructures that were visible-light-responsive due to the resident copper in the lattice. The nanostructures were synthesized through a size-controlled hot-injection process, which was adaptable to the surface ligation processes. The nanostructures were then characterized through transmission electron microscopy, X-ray diffraction, diffused reflectance spectroscopy, Rutherford backscattering, and photoluminescence analysis to measure crystallite nature, size, luminescence, composition, and band-gap analyses. Antiprotozoal efficiency of the current nanoparticles revealed the photodynamic killing of Leishmania protozoan, thus acting as efficient metal-based photosensitizers. The crystalline nanoparticles showed good biocompatibility when tested for macrophage toxicity and in hemolysis assays. The study opens a wide avenue for using toxic material in resident nontoxic forms as an effective antiprotozoal treatment.
\end{abstract}

Keywords: zinc oxide, nanoparticles, doping, photodynamic therapy, Leishmania

\section{Introduction}

Researchers and pharmaceutical industries are striving to find alternative treatment options to control outbreaks of infectious diseases caused by pathogens that are resistant to the currently available drugs. Nowadays, it is generally perceived that nanotechnology may change this scenario by introducing new drug delivery systems, and nanomedicines to replace the currently available standard drugs, particularly in situations where parasites and microbes have developed widespread resistance. ${ }^{1,2}$ Photodynamic therapy (PDT) is a cheap and effective therapy that has been successfully applied for the treatment of topical conditions, such as macular degeneration, skin lesions, cancer, ${ }^{3}$ and cutaneous leishmaniasis. ${ }^{4}$ Generally, PDT is a two-step process that involves the delivery of a photosensitizer, followed by its activation with nonthermal light of a specific wavelength to generate reactive oxygen species (ROS). Singlet oxygen moieties are produced frequently in type II reactions of PDT. ${ }^{5}$ Compared to ground-state oxygen, singlet-state oxygen is highly reactive and very toxic, causing damage to a number of substrates including proteins, nucleic acids (DNA and RNA), lipids, and carbohydrates. ${ }^{6}$ This highly excited energetic form has received serious consideration because of its physical, chemical, and biological properties. The conversion of ground-state oxygen to this highly activated antiparallel spinning molecule requires overcoming the spin restriction: in the first stage, it has two electrons in the outer shell with a normal spin and in the second stage, it has one electron in an opposite spin and is converted into a highly reactive molecule. 
Thus, the highly electrophilic characteristic of singlet oxygen and the non-radical nature have increased its capability for stimulating oxidative reactions with macromolecules without the participation of free radicals. ${ }^{7} \mathrm{TiO}_{2}$ and $\mathrm{ZnO}$ are considered potential photosensitizers for PDT due to their unique phototoxic effect upon irradiation. ${ }^{89}$ The lower cost, nontoxicity, high crystallinity, and being in a similar band to that of $\mathrm{TiO}_{2}$ make $\mathrm{ZnO}$ a suitable and cheap alternative. ${ }^{10}$

A problem that affects the activity of these metal oxides is their large band-gap structure making them UV responsive for electrons-holes generation. $\mathrm{Cu}$ and other dopants may enhance the visible light response through reducing the bandgap of such materials. ${ }^{11} \mathrm{Cu}$ doping may help in enhancing the phototoxic activity through dual mode: addition of more electropositive $\mathrm{Cu}^{2+}$ centers can take excited electrons increasing the life-time of holes in valence band of $\mathrm{ZnCuO}$ structures. Moreover $\mathrm{Cu}$ may induce the visible light sensitivity through narrowing down the conduction band in $\mathrm{ZnCuO}$ structures. ${ }^{12}$

Leishmaniasis caused by Leishmania spp. is a digenetic (heteroxenous) parasitic protozoa of humans and animals. ${ }^{13}$ The disease occurs in different clinical manifestations, that is, ranging from cutaneous to visceral leishmaniasis. Cutaneous leishmaniasis is caused primarily by Leishmania tropica, and this parasite is different from all others in the Old-World Leishmania complex. ${ }^{14}$ L. tropica is strictly limited to human beings and the lesions caused by this species may remain for a longer time. The lesions often resemble flattened volcanoes, becoming firmer as they heal and can last for more than 3 years. ${ }^{13}$

This study focuses on the development of six biocompatible nanoparticles of $\mathrm{ZnO}$ doped with different concentrations of $\mathrm{Cu}(1 \%, 5 \%$, and $10 \%, \mathrm{ZnCuO} 1-\mathrm{ZnCuO} 3)$ and $5 \% \mathrm{~N}$ with $\mathrm{Cu}(1 \%, 5 \%$, and $10 \%, \mathrm{ZnCuO} 4-\mathrm{ZnCuO} 6$, respectively) and their in vitro efficacy against Leishmania parasite. Previously, we had used silver as a dopant ${ }^{15}$ but it produced a lower ROS, and the half maximal inhibitory concentration $\left(\mathrm{IC}_{50}\right)$ against Leishmania cells was not efficient as compared to the currently synthesized $\mathrm{ZnCuO}$ nanoparticles. In the current study, $\mathrm{Cu}$ and $\mathrm{Cu}-\mathrm{N}$ were selected as dopants as they cause multi-electron reduction of oxygen, which produce a higher quantity of lethal ROS in the immediate environment upon exposure to visible portion of light, and thus were more effective photodynamic killers.

\section{Materials and methods Ethics}

The study was approved by the Research Ethical Committee of Biotechnology Department, Quaid-i-Azam University, Islamabad, Pakistan.

\section{Chemicals and apparatus}

Zinc acetate, copper acetate, polyethylene glycol (PEG), ethanol, oleylamine, oleic acid, Ficoll ${ }^{\circledR}$, Percoll ${ }^{\circledR}$, trypan blue, sodium azide, mannitol, and penicillin were purchased from Sigma-Aldrich Co. (St Louis, MO, USA); Medium 199 (M199), Roswell Park Memorial Institute (RPMI), sytox green, and 1,3-Diphenylisobenzofuran (DPBF) from Thermo Fisher Scientific (Waltham, MA, USA); fetal bovine serum (FBS) from PAA Laboratories GmbH (Pasching, Austria); streptomycin from Bio Basic Inc. (Markham, ON, Candada); methylene blue and $\mathrm{HCl}$ from Merck and Co.

\section{Synthesis}

The $\mathrm{ZnCuO}$ nanoparticles were synthesized by a modified Masayuki method. ${ }^{16}$ In a typical reaction, zinc acetate ( $1 \mathrm{mM})$, copper acetate $(0.01,0.05$, and $0.1 \mathrm{mM}$ corresponding to $1 \%, 5 \%$, and $10 \% \mathrm{Cu}$ amount), and oleylamine (5 mM) were added to oleic acid $(10 \mathrm{~mL})$ and stirred at $80^{\circ} \mathrm{C}$ under vacuum for 30 minutes to obtain a clear solution. The solution was heated at $150^{\circ} \mathrm{C}$ for 60 minutes under nitrogen. The reaction temperature was further raised and kept at $300^{\circ} \mathrm{C}$ for 1 hour to generate $\mathrm{ZnCuO}$ nanostructures. The $\mathrm{ZnCuO}$ nanostructures were precipitated by adding ethyl acetate and washed repeatedly with $n$-hexane and ethanol. Air-dried nanoparticles were annealed in oxygen atmosphere for 6 hours at $600^{\circ} \mathrm{C}$ to remove oleic acid capping from the synthesized $\mathrm{ZnCuO}$ nanostructures. For nitrogen doping, $\mathrm{ZnCuO} 4-\mathrm{ZnCuO} 6$ nanostructures were suspended in $5 \mathrm{mM}$ urea dissolved in $10 \mathrm{~mL}$ ethanol and stirred for 3 hours. The resulting suspension was oven dried at $100^{\circ} \mathrm{C}$ and annealed at $400^{\circ} \mathrm{C}$ for 4 hours to obtain nitrogen doping in $\mathrm{ZnCuO}$ nanostructures. Crystalline $\mathrm{ZnCuO} 1-\mathrm{ZnCuO} 6$ nanoparticles were sonicated in $3 \mathrm{wt} \%$ PEG-2000 and incubated for 2 hours to stabilize the nanoparticle surface in biological media toward aggregation. Unbound PEG was removed through centrifugation and washing with ethanol. PEG-bound $\mathrm{ZnCuO}$ nanoparticles were air dried for physical characterization.

\section{Characterization of nanostructures}

The physical characterization of nanostructures was carried out by transmission electron microscopy, X-ray diffraction analysis, diffused reflectance spectroscopy, and Rutherford backscattering analysis. The crystallite sizes were confirmed through transmission electron microscopy analysis on a JEOL JEM-1010 transmission electron microscope (JEOL, Tokyo, Japan). The crystallite nature of $\mathrm{ZnCuO}$ including phases, crystallite structure, and crystalline 
size was measured on a Shimadzo $6000 \mathrm{X}$-ray diffraction machine. Analysis was performed using $\mathrm{Cu}-\mathrm{K} \alpha$ radiation of $\lambda=1.54 \AA$ at $40 \mathrm{kV}$ and the operating current was set at $30 \mathrm{~mA}$. Diffused reflectance spectroscopy was performed on a LAMBDA 950 PerkinElmer UV/VIS/NIR spectrometer (PerkinElmer Inc., Waltham, MA, USA). Rutherford backscattering was carried out to calculate the percentage composition of nanocrystalline samples. Analysis was executed on a 5UDH-2 Pelletron linear tandem accelerator facility using $\mathrm{He}^{2+}$ beam of energy $2.085 \mathrm{MeV}$. The incident angle was kept at $0^{\circ}$ whereas the backscattering angle was $170^{\circ}$. A solid-state barrier detector was used set at $20 \mathrm{keV}$ resolutions. The data were analyzed via XRUMP 2.0 and SIMNRA 6.06.

\section{Biocompatibility of synthesized nanoparticles}

\section{Human macrophages}

Human macrophages were isolated by the Ficoll-Gastrografin ${ }^{\circledR}$ method and their biocompatibility was tested and calculated using a previously used method of Nadhman et al. ${ }^{15}$

\section{Hemolysis assay}

Hemolysis assay was carried out by using a modified method of Nederberg et al. ${ }^{17}$ Briefly, fresh red blood cells (human red blood cells, approved by the review committee of the Biotechnology Department, Quaid-i-Azam University, Islamabad, Pakistan, on February 7, 2014; the subjects also provided informed consent) were washed three to four times with Hank's buffer salt solution (HBSS). Afterward, $180 \mu \mathrm{L}$ of red blood cell suspension in HBSS (4\% in volume) was placed in 96-well plates and $20 \mu \mathrm{L}$ of $\mathrm{ZnCuO}$ particles were added in different concentrations to each well with one group exposed to sunlight for 15 minutes and another group in dark. Afterward, the plates were incubated for 3 hours at $37^{\circ} \mathrm{C}$ with $5 \% \mathrm{CO}_{2}$. The suspended cells were taken and centrifuged at $1,000 \times g$ for 5 minutes. The hemoglobin released was assessed at $576 \mathrm{~nm}$ by taking the supernatant in a 96-well plate and read using a microplate reader (BioTek 96-well plate reader; BioTek Instruments Inc., Winooski, VT, USA). The red blood cell suspension in HBSS without nanoparticles was used as a negative control. Triton X-100 (0.1\%) was taken as a positive control. The following formula was used to calculate the percentage of hemolysis:

\section{Dose and time-dependent in vitro anti- leishmanial activity}

The L. tropica KWH23 cultures were maintained in M199 supplemented with $10 \%$ heat-inactivated FBS, $100 \mathrm{U} / \mathrm{mL}$ penicillin, and $100 \mathrm{mg} / \mathrm{mL}$ streptomycin at $24^{\circ} \mathrm{C}$. The experiments were carried out by our previously used method ${ }^{15}$ with modifications. Briefly, stock solutions of $1 \mathrm{mg} / \mathrm{mL}$ of the different $\mathrm{ZnCuO}$ particles were dissolved in deionized water. Leishmania promastigotes were grown in M199 for 7 days at $24^{\circ} \mathrm{C}$. The cells $\left(1 \times 10^{6} / \mathrm{mL}\right)$ were suspended in a 96-well microtiter plate. They were then treated with serial concentrations of $\mathrm{ZnCuO}$ particles $(0.1 \mathrm{ng} / \mathrm{mL}$ to $100 \mu \mathrm{g} / \mathrm{mL}$ ). The experiments were carried out in four groups. One group each in triplicate was exposed to direct sunlight for 15 minutes, tungsten light $(100 \mathrm{~W})$ with an infrared (IR) filter, and dark. The last group containing only L. tropica KWH23 was exposed to direct sunlight without any $\mathrm{ZnCuO}$ nanoparticles for the purpose of checking the killing effect of sunlight. The experiments were carried out from mid-September to the end of October, February, and March, respectively, during which time the external temperature was maintained between $22^{\circ} \mathrm{C}$ and $25^{\circ} \mathrm{C}$, favorable for the growth of Leishmania. The external temperature was frequently monitored, and no experiments were performed during cloudy weather. The 96-well plates with clean and clear covered lids were exposed to direct sunlight in all the experiments, and the selected time for such exposure was between 11 am and 12 noon. During this time, the sunlight was located perpendicular against the plates, which is better for more exposure of each well of the 96-well plate. Afterward, the microtiter plates were incubated at $24^{\circ} \mathrm{C}$ for 3 , 12 , and 24 hours, respectively, in the dark. The viable cells were counted on neubauer chamber by their motility and also using trypan blue. Their $\mathrm{IC}_{50}$ values were calculated by GraphPad Prism 5 (GraphPad Software, Inc., La Jolla, CA, USA) and also confirmed by SPSS 21 (IBM Corporation, Armonk, NY, USA).

\section{ROS quantification}

DPBF solution was prepared by dissolving $0.1 \mathrm{mM}$ DPBF in ethanol. The synthesized nanoparticles were dissolved in a concentration of $10 \mu \mathrm{g} / \mathrm{mL}$ in $2 \mathrm{~mL}$ of DPBF solution, taken in sealed quartz cuvette, and exposed to sunlight with an IR filter (400-800 $\mathrm{nm}$ ) due to the full degradation of DPBF upon

$$
\text { Hemolysis }(\%)=\frac{\text { OD at } 576 \mathrm{~nm} \text { in the nanoparticle solution }- \text { OD at } 576 \mathrm{~nm} \text { in HBBS }}{\text { OD at } 576 \mathrm{~nm} \text { in } 0.1 \% \text { Triton X-100 }- \text { OD at } 576 \mathrm{~nm} \text { in HBBS }} \times 100
$$


exposure to sunlight for 45 seconds. After each 30 seconds, the absorbance was measured by UV 3000 spectrophotometer (O.R.I., Hamburg, Germany) for up to 5 minutes. Methylene blue was used as a standard. Absorbance was measured and corrected for the degradation of DPBF.

For the identification of possible ROS produced, L. tropica $\mathrm{KWH} 23$ promastigotes were treated with $\mathrm{ZnCuO}$ in two groups and were exposed to sunlight for 15 minutes as in the aforementioned protocol. Sodium azide was added to one group at a concentration of $0.1 \mathrm{mM}$, and $1 \mathrm{mM}$ mannitol was added to the other group. The cells were incubated at $24^{\circ} \mathrm{C}$ for 24 hours in the dark. Viable cells were counted by both trypan blue exclusion and motility of Leishmania cells on the neubauer chamber.

\section{Cell internalization studies (inductively coupled plasma atomic emission spectroscopy)}

Leishmania cells were taken in $2 \mathrm{~mL}$ eppendorf tubes with a higher quantity of Leishmania parasites $\left(2 \times 10^{8}\right.$ cells $\left./ \mathrm{mL}\right)$ and $\mathrm{ZnCuO}$ nanoparticles were added at a concentration of $10 \mu \mathrm{g} / \mathrm{mL}$. The cells were incubated for 3 hours and after that washed three times with phosphate buffer. The cells were then lyzed by incubating in $1.5 \mathrm{M} \mathrm{HCl}$. Quantification of $\mathrm{ZnCuO}$ nanoparticles was carried out by inductively coupled plasma atomic emission spectroscopy (ICP-AES).

\section{Effect on axenic amastigotes and infected macrophages}

Axenic amastigotes were cultured in M199 at pH 4.5 and the culture was maintained at $32^{\circ} \mathrm{C}-33^{\circ} \mathrm{C}$. The rest of the procedure was the same as previously mentioned in the antileishmanial assay. Human macrophages were cultured in 24-well chamber slides to a cell density of $2 \times 10^{4}$ cells per well and 24 hours after adhesion and growth on the chamber slides, monolayers with log-phase promastigotes at a range of infection of 1:10 (macrophage/parasite) were infected and incubated at $37^{\circ} \mathrm{C}$ in $5 \% \mathrm{CO}_{2}$ for 5 days. Washing was done until the removal of non-phagocytosed promastigotes, and $0.1 \mu \mathrm{g} / \mathrm{mL}$ of each $\mathrm{ZnCuO}$ nanoparticle was administered to each well. One group was exposed to total dark and the other to sunlight for 15 minutes. After 24 hours incubation in dark, chamber slides were fixed and stained with absolute methanol and 4\% Giemsa, respectively. The percentage of infected macrophages, as a minimum 100 macrophages per well, was counted and the percent inhibition calculated.

\section{Apoptosis, necrosis, and membrane permeability evaluation}

L. tropica KWH23 promastigotes were treated in two groups. One group was exposed to sunlight for 15 minutes and incubated in dark for 24 hours. The second group was incubated in the dark without any exposure to light. Afterward, both the groups were washed with phosphate buffer. The cells were treated with RNAase $(1 \mathrm{mg} / \mathrm{mL})$. Both the groups were further divided into two more groups. One of the groups was stained with acridine orange $(100 \mu \mathrm{g} / \mathrm{mL})$ and other group with ethidium bromide $(100 \mu \mathrm{g} / \mathrm{mL})$ mixed with acridine orange $(100 \mu \mathrm{g} / \mathrm{mL})$ in a $3: 1$ concentration. The increase in fluorescence was checked on a Leica fluorescent microscope with a Canon camera using 485 and $530 \mathrm{~nm}$ filters for excitation and emission wavelengths, respectively. Nuclear irregularity was measured by ImageJ software (ImageJ 1.48 free version) using the method of Filippi-Chiela et al. ${ }^{18}$

To evaluate membrane permeability, the L. tropica KWH23 promastigotes were treated as mentioned earlier and then washed with HBSS. The cells were stained with $1 \mu \mathrm{M}$ sytox green dye for 15 minutes in dark and then mounted on a slide. The increase in fluorescence was checked on a Leica fluorescent microscope with a Canon camera using 485 and $530 \mathrm{~nm}$ filters for excitation and emission wavelengths, respectively. Triton X-100 (0.1\%) was used as a control for full permeability.

\section{Temperature measurements of $\mathrm{ZnCuO}$ undergoing irradiation}

Different concentrations of $\mathrm{ZnCuO}$ nanoparticles were added $(0.1,1$, and $10 \mathrm{mg} / \mathrm{mL})$ to water, RPMI, and M199 media supplemented with $10 \%$ FBS, respectively. No Leishmania cells were added to the media. They were exposed to sunlight for 15 minutes with temperature probe, and the rise in temperature was recorded with Eutech temperature probe at intervals of 1 minute at ambient environment. The control was also exposed to sunlight for 15 minutes without any $\mathrm{ZnCuO}$ nanoparticles.

\section{Data processing and statistics}

All the experiments were conducted at least three times to confirm their reproducibility and were done each time in triplicate. Statistical analysis was done using SPSS 21 and also with GraphPad Prism 5. The relationship between different parameters was assessed using Pearson's correlation coefficient ( $r$ ). Analysis of variance (ANOVA) was used to check significant mean difference with Tukey's honest significant difference (HSD) for post hoc analysis. Two-way 
ANOVA was used to determine significant mean and interaction effect, followed by the Holm-Sidak method for multiple pairwise comparisons of the marginal means. $P<0.05$ and $P<0.01$ were used to define significant and highly significant results, respectively.

\section{Results and discussion Characterization of synthesized nanostructures}

$\mathrm{ZnCuO}$ nanoparticle characterization is provided in the Supplementary material.

\section{Biocompatibility}

In the current study, the biocompatibility of the synthesized nanoparticles was carried out on human macrophages because Leishmania attack these cells. Interestingly, $\mathrm{ZnCuO}$ particles showed cytotoxic activity at the microgram level against macrophages. Nevertheless, all of the $\mathrm{ZnCuO}$ particles showed an improved therapeutic index; lethal concentration, $50 \%\left(\mathrm{LC}_{50}\right)$ for this cell type was a 1,000-fold higher than for Leishmania. This was because of the macrophage capability to cope with ROS as they are produced to act as defensive bullets against pathogens. ${ }^{19}$ Although, the therapeutic index was higher, it can be elucidated (Figure 1) that increasing the concentration of dopant increased toxicity; for example, the $\mathrm{LC}_{50}$ of non-doped $\mathrm{ZnO}(\mathrm{ndZnO})$ was $122 \pm 14.52 \mu \mathrm{g} / \mathrm{mL}$ while that of $\mathrm{ZnCuO} 6$ was $44 \pm 8.90 \mu \mathrm{g} / \mathrm{mL}$. But according to George et al, ${ }^{20}$ the cytotoxicity of photocatalytic ndZnO is reduced if its dissolution within culture media is inhibited by doping. However, higher concentrations of dopant might be responsible for the release of dopant ions. In the experiments in dark, the current nanoparticles were found to be toxic at higher concentrations $(>200 \mu \mathrm{g} / \mathrm{mL})$ to these macrophage cells. ${ }^{21}$

Furthermore, biocompatibility was also assessed on red blood cells. The cationic agents have major harmful side effects including hemolysis. ${ }^{17}$ In the current study, different concentrations of the $\mathrm{ZnCuO}$ nanoparticles were used to assess the hemolytic activity. Interestingly, after incubation, the $\mathrm{ZnCuO}$ nanoparticles have shown little hemolysis at $200 \mu \mathrm{g} /$ $\mathrm{mL}$, without damaging the membrane of the red blood cells. Moreover, at such concentrations, $\mathrm{ZnCuO}$ has successfully damaged the Leishmania surface, as the surface charge of trypanosomatids is highly negative, ${ }^{22}$ and this might be the reason for the increased uptake of $\mathrm{ZnCuO}$ particles by Leishmania (confirmed by ICP-AES), thus increasing the killing and disruption of cell membrane (confirmed by sytox green). However, high concentrations of $\mathrm{ZnCuO}$ nanoparticles have shown higher hemolysis $(60 \%-100 \%)$ using 500 and $1,000 \mu \mathrm{g} / \mathrm{mL}$ as metal oxides are toxic at higher concentrations. ${ }^{23}$

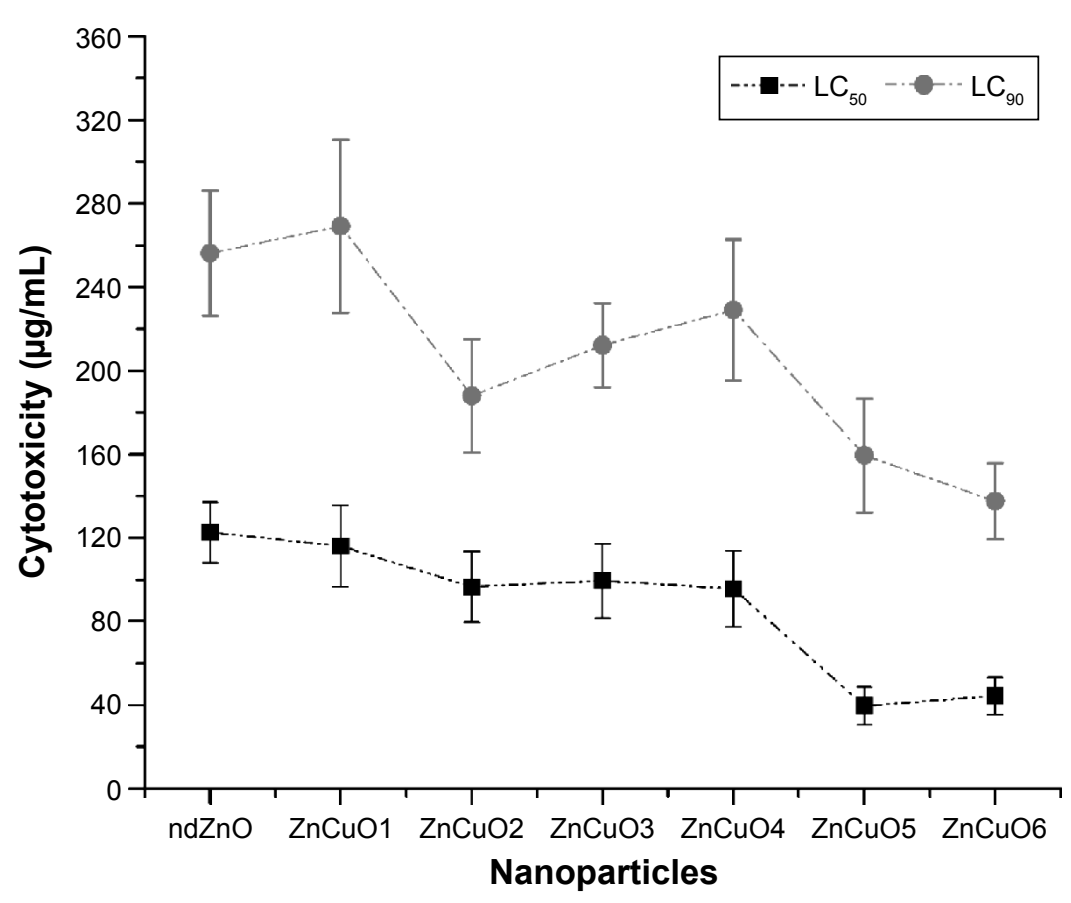

Figure I Biocompatibility of both non-doped $\mathrm{ZnO}$ and $\mathrm{ZnCuO}$ particles against macrophages.

Notes: Macrophages were treated with synthesized nanoparticles and exposed to sunlight for 15 minutes, then incubated in standard conditions. $\mathrm{LC}_{50}$ and LC $_{90}$ were calculated by SPSS 21 .

Abbreviations: $\mathrm{LC}_{50}$, lethal concentration, $50 \%$; $\mathrm{LC}_{90}$, lethal concentration, $90 \%$. 


\section{Dose and time-dependent in vitro antileishmanial activity}

In the current study, the solubility of $\mathrm{ndZnO}$ and $\mathrm{ZnCuO}$ nanostructures was first tested at different concentrations such as 10,5 , and $1 \mathrm{mg} / \mathrm{mL}$ in culture media. It was found that the highest concentrations ( 10 and $5 \mathrm{mg} / \mathrm{mL}$ ) of $\mathrm{ZnCuO}$ showed some precipitation after 24 hours. The particles were soluble and stable for 36 hours at a concentration of $1 \mathrm{mg} / \mathrm{mL}$ in culture media (M199 and RPMI); this is the reason for $1 \mathrm{mg} / \mathrm{mL}$ of stock solution being used for these experiments. Leishmania promastigote cells were treated with the serial dilutions of $\mathrm{ZnCuO}$ nanoparticles $(0.1 \mathrm{ng} / \mathrm{mL}$ to $100 \mu \mathrm{g} / \mathrm{mL})$ in different light conditions, that is, exposing the cells with nanoparticles to direct sunlight, in tungsten light $(100 \mathrm{~W})$ with an IR filter and in dark for 15 minutes each. Afterward, the cells were incubated at $24^{\circ} \mathrm{C}$ for 3,12 , and 24 hours in total dark. The cell killing started from the first hour at 100 and $10 \mu \mathrm{g} / \mathrm{mL}$ of $\mathrm{ZnCuO}$ particles. In the first hour, the killing percentage was $20 \%-25 \%$, while in the second hour, it reached $75 \%-80 \%$ and further to $100 \%$ at the third hour after exposure to direct sunlight (Figure 2). Dose-dependent activity of the synthesized nanoparticles showed the $\mathrm{IC}_{50}$ in the $\mu \mathrm{g}$ and ng levels in direct sunlight (Figure 3). In tungsten light with IR filter, $100 \%$ killing was achieved after 12 hours at 100 and $10 \mu \mathrm{g} / \mathrm{mL}$. As for sunlight, the global luminous efficacies (white light proportion) are approximately 105 $\mathrm{lm} / \mathrm{W}$ for clear skies and for average conditions. Similarly, tungsten light luminous efficiency is approximately $16.7 \mathrm{~lm} / \mathrm{W}$ (only $2.4 \%$ visible region luminosity) for a $100 \mathrm{~W}$ bulb. ${ }^{24}$ Tungsten light is powerful, but a major portion of the emitted radiations from a tungsten source is in the IR region ${ }^{25}$ and is of little use for the PDT. Therefore, we used the IR filter to

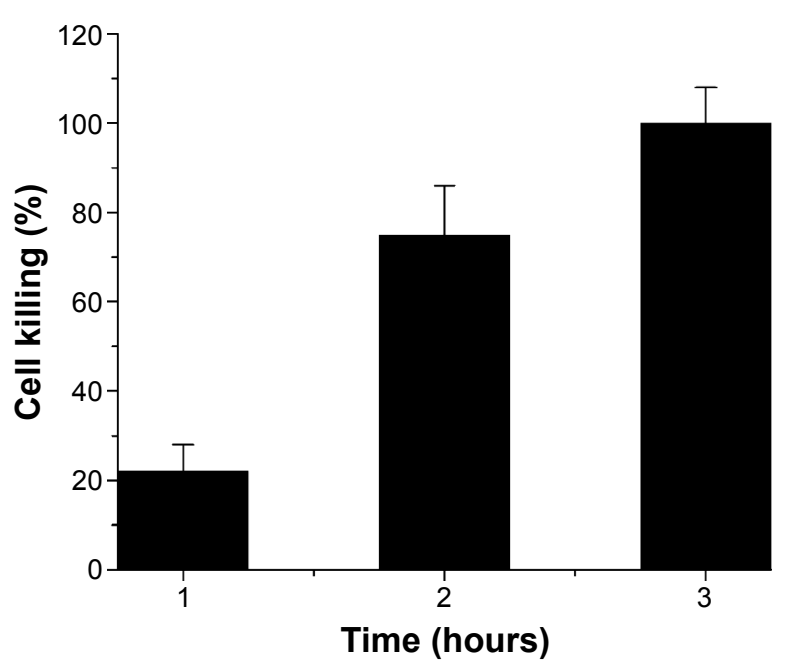

Figure 2 Time-dependent activity of all the $\mathrm{ZnCuO}$ nanoparticles against the promastigotes of Leishmania tropica (mean percent killing of $\mathrm{ZnCuO}$ nanoparticles).

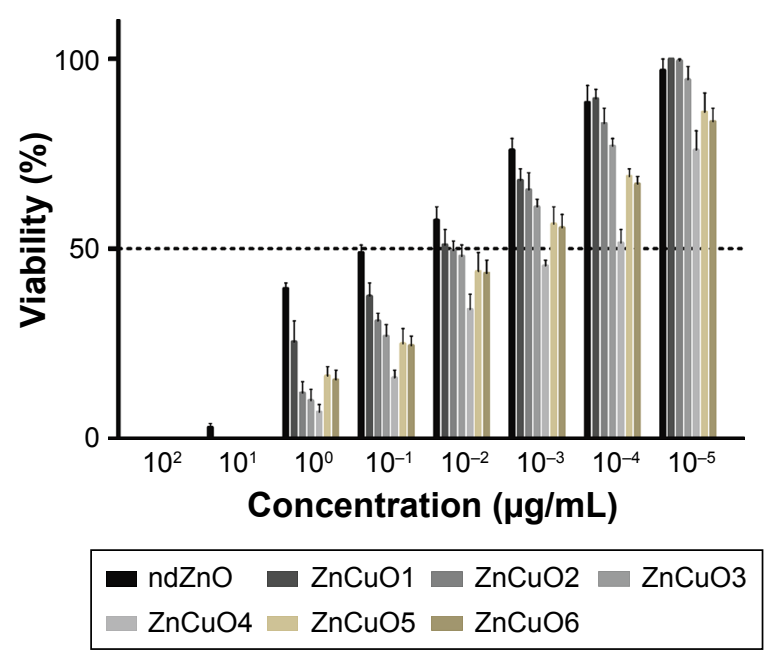

Figure 3 Dose-dependent activity of the synthesized nanoparticles against Leishmania tropica.

Notes: The 96-well plates with transparent, clear, and clean lids were exposed to direct sunlight for 15 minutes with an external temperature of between $22^{\circ} \mathrm{C}$ and $25^{\circ} \mathrm{C}$ between $\mathrm{II}$ am and 12 noon, and afterward incubated in the dark for 24 hours at $24^{\circ} \mathrm{C}$.

Abbreviation: nd, non-doped.

filter the IR radiations from a tungsten source. Further, the $\mathrm{ZnCuO}$ nanoparticles were activated by the visible region of light as inferred from diffused reflectance spectroscopy and photoluminescence; thus, there was more killing when exposed to direct sunlight than that to tungsten light.

Dopants in higher concentration are toxic to cell $\mathrm{s}^{26}$ and it was found that there was no killing in dark by the $\mathrm{ZnCuO}$ nanoparticles except $\mathrm{ZnCuO} 6$ that showed $10 \%$ cell killing, which may be the toxicity of a higher dopant concentration. But, in case of other $\mathrm{ZnCuO}$ particles, the resident dopant in lattice resulted in decreased toxicity but increased the photokilling capability of nanoparticles against protozoa.

Based on Figure 4, the best $\mathrm{IC}_{50}$ values were in the order: $\mathrm{ZnCuO} 3>\mathrm{ZnCuO} 6>\mathrm{ZnCuO} 5>\mathrm{ZnCuO} 4>\mathrm{ZnCuO} 2>$ $\mathrm{ZnCuO} 1$. The bars in Figure 4 represent the confidence intervals of data set, which showed a significant relation $(P<0.05)$ between $\mathrm{ZnCuO}$ nanoparticles.

However, statistical analysis grouped $\mathrm{ZnCuO} 2$ and $\mathrm{ZnCuO} 4$ and also $\mathrm{ZnCuO} 5$ and $\mathrm{ZnCuO} 6$ as having no significant difference ( $P>0.05$ at $95 \%$ confidence interval) while both $\mathrm{ZnCuO} 1$ and $\mathrm{ZnCuO} 3$ were found highly significant $(P<0.01$ at $95 \%$ confidence interval) in comparison with other $\mathrm{ZnCuO}$ nanoparticles showing the effect of low and high concentrations of dopant in the $\mathrm{ZnO}$ lattice.

\section{ROS quantification and identification}

DPBF is a fluorescent dye normally used for the quantification of ROS, especially the singlet oxygen and hydroxyl radicals. ${ }^{27}$ This dye is sensitive to ROS and rapidly decolorizes. The dye 


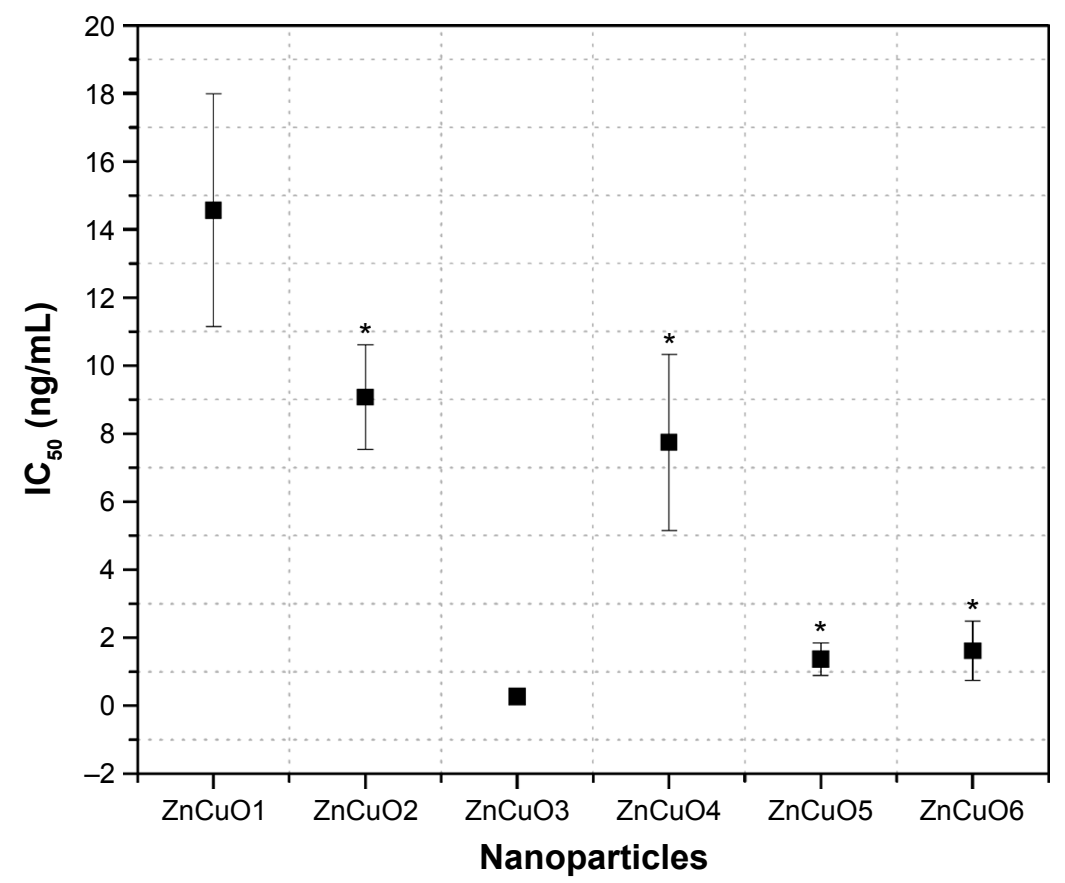

Figure 4 Statistical comparison of $\mathrm{IC}_{50}$ of $\mathrm{ZnCuO}$ particles against Leishmania tropica $\mathrm{KWH} 23$ in direct sunlight after 24 hours (bars indicate $95 \%$ confidence intervals). Note: *Indicates no statistical difference at $P>0.05$.

Abbreviation: $I C_{50}$, half maximal inhibitory concentration.

degradation is rate dependent. Furthermore, the dye is also sensitive to sunlight and free oxygen. DPBF was used as a chemical quencher of ROS, and quantification was done using the following equation:

$$
\Phi_{\Delta \mathrm{ZnCuO}}=\Phi_{\mathrm{MB}}\left(\mathrm{k}_{\mathrm{ZnCuO}} / \mathrm{k}_{\mathrm{standard}}\right)
$$

where $\Phi \Delta \mathrm{ZnCuO}$ is the quantum yield of semiconductor nanoparticles and $\Phi \Delta \mathrm{MB}$ is the quantum yield of methylene blue. The yield from DPBF quenching was more than the normal quencher, ie, methylene blue (quantum yield of 0.52 ), as in the case of $\mathrm{ZnCuO3}$, the quantum yield was $0.632 \pm 0.13$. Currently, it was found that the ROS quantum yield by $1 \%$

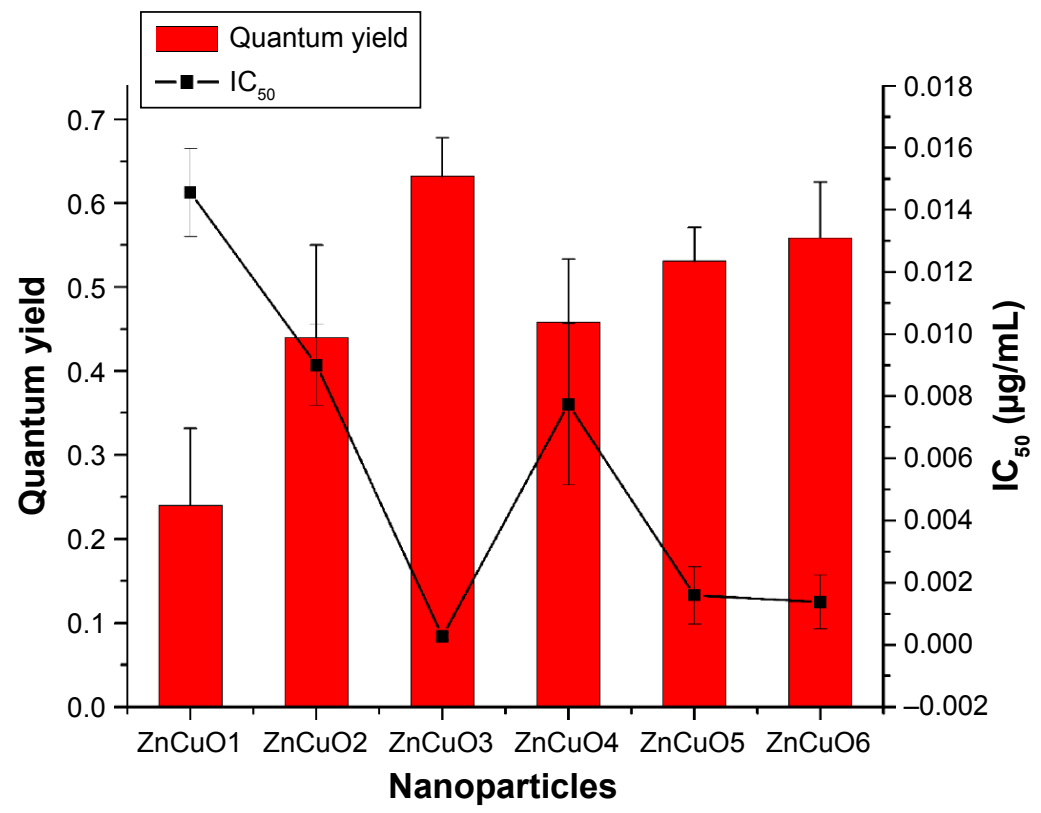

Figure 5 The inverse relation between reactive oxygen species (ROS) and $\mathrm{IC}_{50}$ of $\mathrm{ZnCuO}$ particles.

Note: The left side of scale shows the quantum yield of ROS, while the right side scale shows the $\mathrm{IC}_{50}$ of $\mathrm{ZnCuO}$ particles against Leishmania promastigotes. Abbreviation: $\mathrm{IC}_{50}$, half maximal inhibitory concentration. 
of $\mathrm{Cu}$ was $0.24 \pm 0.052$, while it increased to $0.44 \pm 0.1$ in the case of $5 \%$ of $\mathrm{Cu}$ (Figure 5).

A highly significant correlation (Pearson's, $r=1$ ) was found among the ROS and $\mathrm{IC}_{50}$, which showed that ROS has an inverse relation with $\mathrm{IC}_{50}$ of nanoparticles $(P<0.01)$, as the more is ROS the less is $\mathrm{IC}_{50}$. $\mathrm{ZnO}$ nanoparticles have the capability to produce a lesser amount of $\operatorname{ROS}^{28}$ but having $10 \%$ of $\mathrm{Cu}$ as impurity in $\mathrm{ZnO}$, it had produced a higher amount of ROS and hence it is required in a lesser quantity to kill the pathogen.

Moreover, to compare the amount of ROS produced by each of the synthesized nanoparticle, a one-way ANOVA was performed, which showed that the effect of nanoparticle type on the production of ROS was significant $(P<0.05)$ (Supplementary material). The pairwise comparison revealed that the difference mainly existed between the nanoparticle used $(P<0.05)$. Meanwhile, the effect with nanoparticle type was present due to a significant difference in $\mathrm{ndZnO}$ and $\mathrm{ZnCuO}$ nanoparticles to produce $\mathrm{ROS}(P<0.05)$. ROS production using ndZnO was significantly lower compared to $\mathrm{ZnCuO}(P<0.05)$ as confirmed by the pairwise comparison, portraying the positive effect of dopant in the $\mathrm{ZnO}$ lattice.

Essentially, DPBF quenches the singlet oxygen and to some extent the hydroxyl radicals $\left(\mathrm{OH}^{\prime}\right)$. In the current study, it was found that $\mathrm{ZnCuO}$ nanoparticles produced more of the singlet oxygen. The concentration of these singlet moieties was calculated by introducing quenchers such as sodium azide..$^{29,30}$ The survival of Leishmania was directly proportional to the scavenging of the particular ROS type. $\mathrm{ZnCuO} 3$ was found to produce the maximum amount of singlet oxygen (Figure 6) and it was considered that the significant $\mathrm{IC}_{50}$ value of $\mathrm{ZnCuO3}$ was due to the increase of ROS production especially singlet oxygen.

The production of these moieties started when an equal or high energy light irradiated the nanoparticle surface; it promoted the valence band electrons to the conduction band and produced a hole in the leaving region. Thus, a recombination reaction started producing electron-hole pairs. ${ }^{31}$ To minimize the recombination reaction, the charge carriers were trapped by the introduction of $\mathrm{Cu} .{ }^{32}$ Thus, it enhanced the photocatalytic activity by producing more ROS due to the surface-to-volume ratio that resulted in more surface oxygen vacancies. ${ }^{33}$ Moreover, the dopant increased the surface defects, and a space charge layer was formed on the surface, which was beneficial for hindering the combination of photoinduced electron-hole pairs. ${ }^{31,34}$ But producing excess of hindrance had decreased the ROS yield, for example, in the case of $\mathrm{ZnCuO} 5$ and $\mathrm{ZnCuO} 6$ particles where the increase in dopant decreased the production of ROS.

The lifetime of singlet oxygen is very short (ie, $3 \mu \mathrm{s}$ ); ${ }^{35}$ so, it has the capability to react with the available macromolecules such as proteins, lipids, or nucleic acids. Singlet oxygen also has the capability to react with the surrounding water molecules to give rise to further ROS moieties such as hydroxyl radicals, hydroxyl ions, hydrogen peroxide, and superoxide molecules. ${ }^{30}$ For the hydroxyl radicals, it is

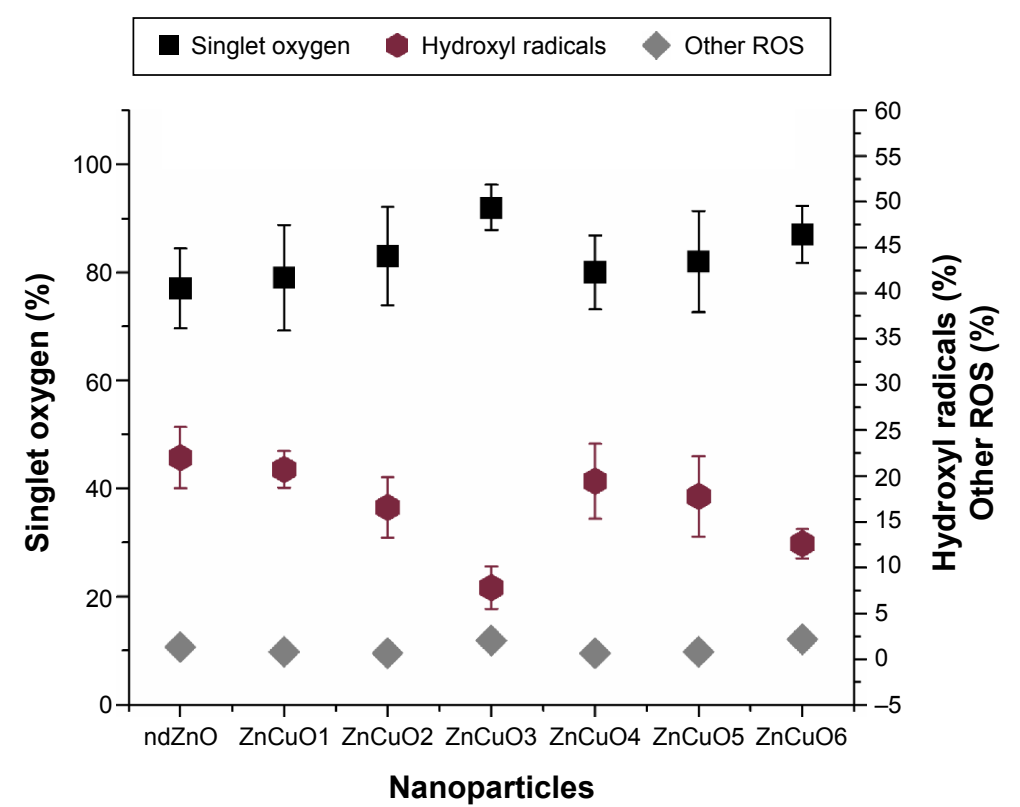

Figure 6 Percentage production of reactive oxygen species (ROS) moieties by the $\mathrm{ZnCuO}$ nanoparticles using $0 . \mathrm{I} \mathrm{mM}$ sodium azide and I mM mannitol as singlet oxygen and hydroxyl radical scavengers.

Abbreviation: nd, non-doped. 
also possible that on the surface of nanoparticles, the holes produced in the recombination reaction abstracted electrons from the water molecule through an oxidative process and thus produced hydroxyl radicals. ${ }^{28,36}$ To compare the total amount of hydroxyl radicals formed by either the recombination reaction on nanoparticle surface or singlet oxygen, a two-way ANOVA was performed. It showed that the effect of the nanoparticle type and singlet oxygen on the production of hydroxyl radical was significant $(P<0.05)$. The hydroxyl radicals produced were $7.8 \%$ by $\mathrm{ZnCuO3}$, while $12.6 \%$, $16.6 \%, 17.8 \%, 19.4 \%$, and $20.7 \%$ were produced by $\mathrm{ZnCuO6}$, $\mathrm{ZnCuO} 2, \mathrm{ZnCuO} 5, \mathrm{ZnCuO} 4$, and $\mathrm{ZnCuO} 1$, respectively particles, respectively. The remaining point percent of ROS were hydroxyl ions and hydrogen peroxide.

\section{Cell internalization studies (ICP-AES)}

Delivery of the nanoparticle to the cell is an important aspect of drug delivery. PEG-coated $\mathrm{ZnCuO}$ particles have the capability to obtain entry into the cell. In the current study, it was found that PEG containing the $\mathrm{ZnCuO}$ nanoparticles were accumulated more inside the Leishmania cells as well as its circulation was also increased. ${ }^{37}$ The delivery of the nanoparticles was concentration dependent as an increase of dopant increased the entry of $\mathrm{ZnCuO}$ particles. In the case of $\mathrm{ndZnO}$, the zinc concentration was $0.98 \pm 0.06 \mu \mathrm{g} / \mathrm{mL}$ while that of $\mathrm{ZnCuO} 3$ was $1.48 \pm 0.28 \mu \mathrm{g} / \mathrm{mL}$ whereas in the control, zinc concentration was $0.023 \pm 0.009 \mu \mathrm{g} / \mathrm{mL}$ and the $\mathrm{Cu}$ concentration ranged from 0.01 to $0.023 \mu \mathrm{g} / \mathrm{mL}$ while there was no $\mathrm{Cu}$ in the control cells (Figure 7). Dopant decreased the dissolution of $\mathrm{Zn}^{2+}$ and thus increased the uptake of $\mathrm{Zn} .{ }^{20}$ Further, the dissolution of these nanoparticles depends on the acidic environment of the lysosomes and calveolar compartments of the cell. ${ }^{38} \mathrm{It}$ is also possible that the cationic nanoparticles enter by electro-migration or electroosmosis in the case of bulk fluid flow across the charged membrane surface ${ }^{39}$ Thus, this made these particles more toxic to Leishmania cells.

\section{Effect on axenic amastigotes and infected macrophages}

Axenic amastigote susceptibility was assessed by treating the axenic Leishmania amastigotes with synthesized nanoparticles. In the current study, it was found that the amastigotes were 1-2.5-fold more resistant than the promastigotes. Regarding the infected macrophages, the experiments were carried out in two phases. In the first phase, the experiments were started by incubating the infected macrophages with $0.1 \mu \mathrm{g} / \mathrm{mL}$ of nanoparticles and they were exposed to sunlight for 15 minutes and afterward incubated in dark for 24 hours. The amastigote killing was $55 \%$ in the macrophages while the axenic amastigotes were killed $100 \%$ at this concentration. In the second phase, the infected macrophage cells were incubated with the nanoparticles and kept in dark for 1-2 hours for the cells to take up the nanoparticles. Afterward, the treated cells were exposed to sunlight for 15 minutes and then

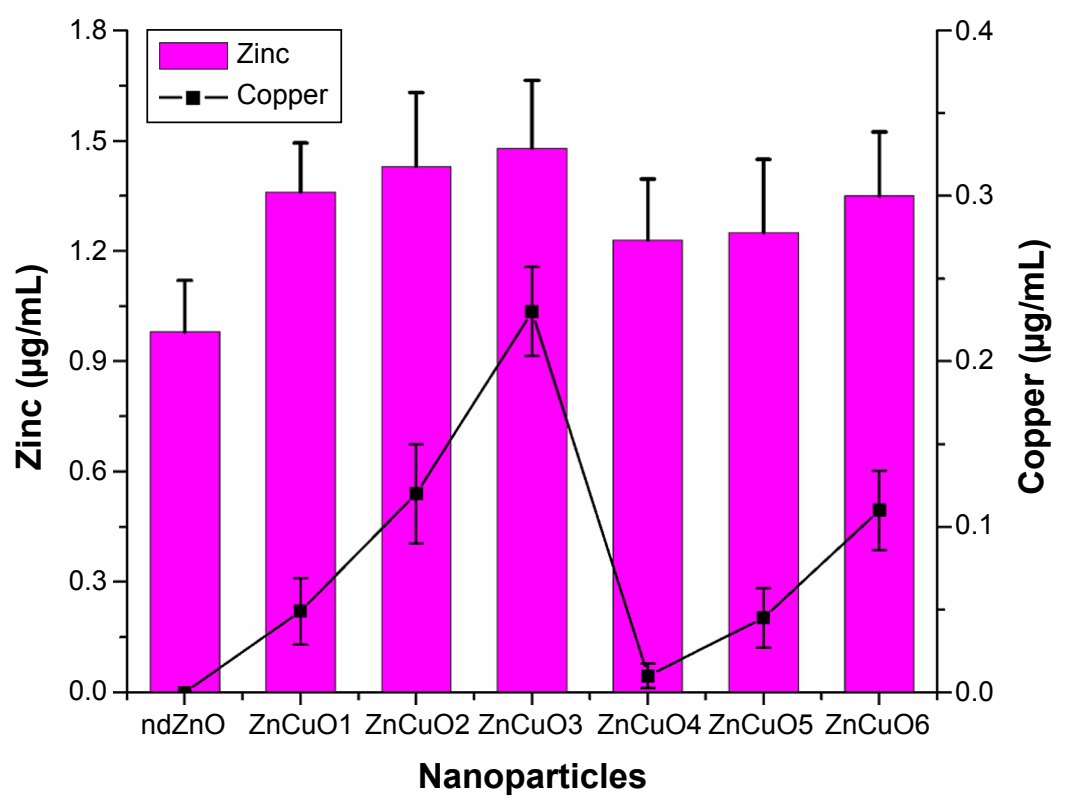

Figure $7 \mathrm{ZnCuO}$ nanoparticles internalization in Leishmania cells.

Note: Comparison of $\mathrm{Zn}$ (left scale) and $\mathrm{Cu}$ (right scale) intake by Leishmania cells $(P<0.05)$.

Abbreviation: nd, non-doped. 


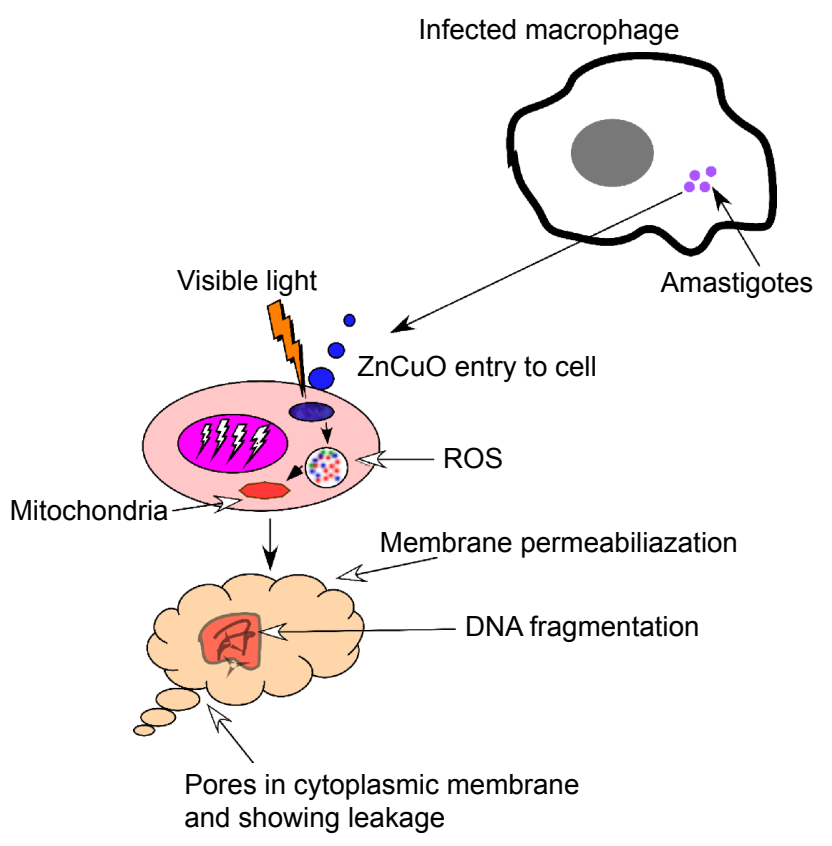

Figure 8 A small cell showing a macrophage infected with amastigotes (purple circles).

Notes: Alteration in nuclear morphology of amastigote occurred in physiological situations and in several processes associated with cell death. These modifications include nuclear condensation and fragmentation observed in apoptosis, decrease in nuclear size, and an increase in nuclear irregularity because of the stress produced by the $\mathrm{ZnCuO}$ particles by producing reactive oxygen species (ROS).

incubated in standard conditions. The results were quite remarkable as the amastigote killing reached $100 \%$ by all the $\mathrm{ZnCuO}$ particles. This increase in amastigote killing was due to the uptake of more $\mathrm{ZnCuO}$ molecules, and after exposure to sunlight, it produced more ROS that helped the immune cells to achieve more killing. ${ }^{40}$ Superior efficacies of the nanoparticles were primarily accredited due to their improved localization in macrophage cells because the PEG coating enhanced the uptake of nanoparticles. ${ }^{41}$ Furthermore, the negatively charged surface on nanoparticles provided a colloidal dispersion that was helpful to entrap the amastigotes (Figure 8).
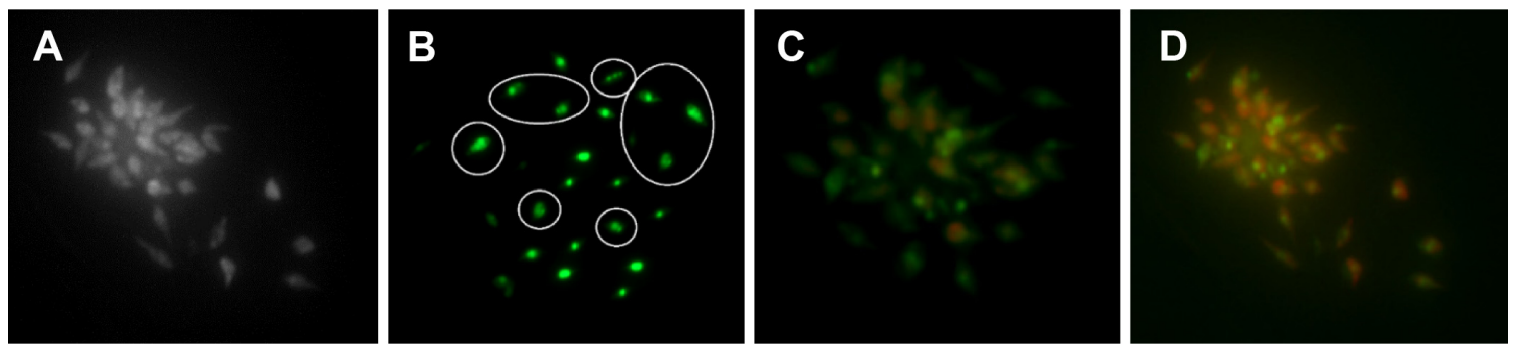

Figure 9 Apoptosis and necrosis of Leishmania cells after exposure to $\mathrm{ZnCuO3}$ particles for I and 3 hours.

Notes: (A) Bright field image; (B) cell exposure to $\mathrm{ZnCuO3}$ particles at I hour; the encircled regions show the formation of apoptotic bodies within the cells with some showing early apoptosis (light green); (C) apoptotic and necrotic cells at I hour exposure to $\mathrm{ZnCuO3}$ particles, with $50 \%$ of the cells showing necrosis and the remaining show early and late apoptosis; and (D) apoptotic and necrotic cells at 3 hours exposure to $\mathrm{ZnCuO3}$ particles. Almost $90 \%$ of the cells show necrosis and the remaining show early and late apoptosis.

\section{Apoptosis, necrosis, and membrane permeability evaluation}

Apoptosis is a multistep and complex program cell death pathway, which occurs in every cell. ${ }^{42}$ Microscopic visualization of staining cells with suitable dye is a primary technique to study the biological mechanisms. ${ }^{43}$ Upon treatment of Leishmania cells with $\mathrm{ZnCuO}$ particles, the cells were treated with apoptotic dye. Acridine orange and ethidium bromide was used for necrosis, as both the dyes attach to nucleic acids in the nucleus upon entry to the cell and emit the respective green and orange colors. ${ }^{44}$ The Leishmania cells initially started the apoptosis as the chromatin material condensation started with light green nuclei showing early apoptosis in first hour of exposure. The formation of apoptotic bodies by the condensation and fragmentation of cellular bodies, especially in the cytoplasm and nucleus, were the main features of apoptosis (Figure 9) ${ }^{45}$ The event started by the activation of caspase cascade thus initiated the death receptors that led to the biochemical changes. These changes were initiated by the nucleus shrinkage and condensation of chromatin material, which led to the DNA fragmentation and caused the formation of apoptotic bodies and then to cell death. ${ }^{46}$ When the cells were exposed for 3 hours or more, ethidium bromide entered the cell indicating the necrosis of cells by emitting an orange color. Upon observation on ImageJ, the cells showed a nuclear irregularity index and many of the Leishmania cells were necrotic and few were apoptotic. In the first hour, more than $90 \%$ cells were apoptotic, while in the third hour almost $90 \%$ cells were necrotic using $0.1 \mu \mathrm{g} / \mathrm{mL}$ of $\mathrm{ZnCuO} 3$.

For the confirmation of apoptotic dyes to penetrate the membrane, the cell membrane permeability was checked by sytox green dye, which entered the cell upon permeability of cell membrane and attached itself to the nucleic acid and emitted a green fluorescence. Singlet oxygen is lethal to biomembranes, causing oxidation and degradation. ${ }^{47} \mathrm{ZnCuO} 3$-treated 


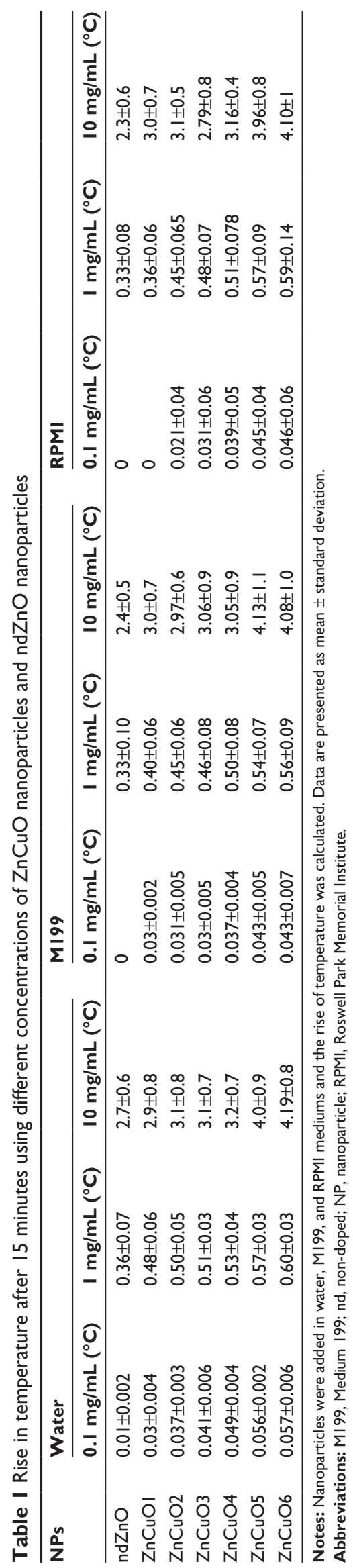

Leishmania cells emitted the green fluorescence confirming the permeability of membrane by the ROS produced.

\section{Temperature measurements of $\mathrm{ZnCuO}$ undergoing irradiation}

These experiments were carried out in water, M199, and RPMI containing 10\% FBS, in the absence of Leishmania cells, with different quantities of ndZnO and $\mathrm{ZnCuO}$ particles. The results were assessed after each minute by exposing them to direct sunlight. The results showed that increasing the concentration of dopant increased the temperature. The $\mathrm{ZnCuO}$ nanoparticles showed a small increase in temperature at $0.1 \mathrm{mg} / \mathrm{mL}$ from $0.01{ }^{\circ} \mathrm{C}$ to $0.057^{\circ} \mathrm{C}$ (Table 1). The temperature increased from $0.48^{\circ} \mathrm{C}$ to $0.6^{\circ} \mathrm{C}$ when $1 \mathrm{mg} / \mathrm{mL}$ of each $\mathrm{ZnCuO}$ nanoparticles was added in water. However, the temperature increase in M199 and RPMI was in the range of $0.46^{\circ} \mathrm{C}-0.56^{\circ} \mathrm{C}$ and $0.36^{\circ} \mathrm{C}-0.59^{\circ} \mathrm{C}$, respectively. The increase in the temperature was high up to $4.19^{\circ} \mathrm{C}$ using $\mathrm{ZnCuO6}$ in water, while in RPMI and M199, it was up to $4.10^{\circ} \mathrm{C}$ and $4.08^{\circ} \mathrm{C}$ at $10 \mathrm{mg} / \mathrm{mL}$, respectively. Thus, this eliminated the involvement of hyperthermia in the killing of Leishmania cells as the $\mathrm{IC}_{50}$ values were in $\mathrm{ng} / \mathrm{mL}$.

\section{Conclusion}

In conclusion, it is elucidated that the $\mathrm{ZnCuO}$ nanostructures, especially $\mathrm{ZnCuO} 1$ to $\mathrm{ZnCuO5}$, can be used against protozoan diseases such as leishmaniasis because of biocompatibility and better ROS yield. Further, the emission peak existed at 640-690 nm, observed in photoluminescence representing the excitation of the current nanoparticles in visible region, which is very useful for PDT. This visible emission of the $\mathrm{ZnCuO}$ nanoparticles will also offer new dimensions to the display materials and their uses in luminescent display. The study showed $\mathrm{ZnCuO}$ nanoparticle optimization of dopant for the ROS production and also their use as antileishmanial agents by examining their effects on various cellular parameters of promastigote and amastigote forms. The nanoparticles generated measurable quantities of singlet oxygen. The synthesized particles were found more efficient than conventional molecular PDT agents (based on $\mathrm{IC}_{50}$ values) as they were more effective at lower concentrations to Leishmania parasites. Also, the $\mathrm{ZnCuO}$ particles were not toxic to normal cells both in light as well as in dark conditions. The cell-killing ability was only in the presence of visible light by the production of more ROS. These ROS caused oxidative stress, membrane permeability, and induced programmed death of the Leishmania cell. The synthesis of these nanoparticles is highly stable and repeatable. Further 
investigations are required to elucidate the biocompatibility and biosafety of such particles in vivo.

\section{Acknowledgments}

The authors are grateful to Dr Nazma Habib and Professor Akram Shah from the Department of Zoology, University of Peshawar, Pakistan, for providing the strain KWH23 that was acquired in 2010 during Dr Nazma's PhD program at the London School of Hygiene and Tropical Medicine, London, UK. The authors are also thankful to Dr Turab Ali Abbas (Experimental Physics Laboratory, National Centre for Physics, Islamabad, Pakistan) for providing the Rutherford backscattering analysis facility and the Biosciences Research Center (BRC) (Islamabad, Pakistan) for the fluorescent microscope facility.

\section{Disclosure}

The authors report no conflicts of interest in this work.

\section{References}

1. Morones JR, Elechiguerra JL, Camacho A, et al. The bactericidal effect of silver nanoparticles. Nanotechnology. 2005;16(10):23-46.

2. Kim BY, Rutka JT, Chan WC. Nanomedicine. N Engl J Med. 2010; 363(25):2434-2443.

3. Gollnick S, Evans S, Baumann H, et al. Role of cytokines in photodynamic therapy-induced local and systemic inflammation. Br J Cancer. 2003;88(11):1772-1779.

4. Akilov OE, Kosaka S, O'Riordan K, et al. The role of photosensitizer molecular charge and structure on the efficacy of photodynamic therapy against Leishmania parasites. Chem Biol. 2006;13(8): 839-847.

5. Agostinis P, Berg K, Cengel KA, et al. Photodynamic therapy of cancer: an update. CA Cancer J Clin. 2011;61(4):250-281.

6. Brynildsen MP, Winkler JA, Spina CS, MacDonald IC, Collins JJ. Potentiating antibacterial activity by predictably enhancing endogenous microbial ROS production. Nat Biotechnol. 2013;31(2):160-165.

7. Agnez-Lima LF, Melo JT, Silva AE, et al. DNA damage by singlet oxygen and cellular protective mechanisms. Mut Res. 2012;751(1): $15-28$.

8. Zhang S, Yang D, Jing D, et al. Enhanced photodynamic therapy of mixed phase TiO2(B)/anatase nanofibers for killing of HeLa cells. Nano Res. 2014;7(11):1659-1669.

9. Arooj S, Nazir S, Nadhman A, et al. Novel ZnO: Ag nanocomposites induce significant oxidative stress in human fibroblast malignant melanoma (Ht144) cells. Beilstein J Nanotechnol. 2015;6(1): $570-582$.

10. Hariharan C. Photocatalytic degradation of organic contaminants in water by ZnO nanoparticles: revisited. Applied Catalysis A General. 2006; 304:55-61.

11. Irie $\mathrm{H}$, Miura S, Kamiya K, Hashimoto K. Efficient visible lightsensitive photocatalysts: Grafting $\mathrm{Cu}(\mathrm{II})$ ions onto $\mathrm{TiO}_{2}$ and $\mathrm{WO}_{3}$ photocatalysts. Chem Phys Lett. 2008;457(1-3):202-205.

12. Yu H, Irie $\mathrm{H}$, Hashimoto $\mathrm{K}$. Conduction band energy level control of titanium dioxide: toward an efficient visible-light-sensitive photocatalyst. J Am Chem Soc. 2010;132(20):6898-6899.

13. Jacobson RL. Leishmania tropica (Kinetoplastida: Trypanosomatidae): a perplexing parasite. Folia Parasitol (Praha). 2003;50(4):241-250.

14. Hanafi HA, El-Din el SM, El-Hossary SS, et al. Experimental acquisition, development, and transmission of Leishmania tropica by Phlebotomus duboscqi. Acta Trop. 2013;125(1):37-42.
15. Nadhman A, Nazir S, Khan MI, et al. PEGylated silver doped zinc oxide nanoparticles as novel photosensitizers for photodynamic therapy against Leishmania. Free Radic Biol Med. 2014;77:230-238.

16. Kanehara M, Koike H, Yoshinaga T, Teranishi T. Indium tin oxide nanoparticles with compositionally tunable surface plasmon resonance frequencies in the near-IR region. $J$ Am Chem Soc. 2009;131(49): 17736-17737.

17. Nederberg F, Zhang Y, Tan JP, et al. Biodegradable nanostructures with selective lysis of microbial membranes. Nature Chem. 2011;3(5): 409-414.

18. Filippi-Chiela EC, Oliveira MM, Jurkovski B, Callegari-Jacques SM, da Silva VD, Lenz G. Nuclear morphometric analysis (NMA): screening of senescence, apoptosis and nuclear irregularities. PLoS One. 2012; $7(8): \mathrm{e} 42522$.

19. Haidaris C, Bonventre PF. A role for oxygen-dependent mechanisms in killing of Leishmania donovani tissue forms by activated macrophages. J Immunol. 1982;129(2):850-855.

20. George S, Pokhrel S, Xia T, et al. Use of a rapid cytotoxicity screening approach to engineer a safer zinc oxide nanoparticle through iron doping. ACS Nano. 2009;4(1):15-29.

21. Prach M, Stone V, Proudfoot L. Zinc oxide nanoparticles and monocytes: impact of size, charge and solubility on activation status. Toxicol Appl Pharmacol. 2012;266:19-26.

22. Souto-Padrón T. The surface charge of trypanosomatids. An Acad Bras Cienc. 2002;74(4):649-675.

23. Jeng HA, Swanson J. Toxicity of metal oxide nanoparticles in mammalian cells. J Environ Sci Health A Tox Hazard Subst Environ Eng. 2006; 41(12):2699-2711.

24. Littlefair PJ. The luminous efficacy of daylight: a review. Lighting Research and Technology. 1985;17(4):162-182.

25. MacIsaac D, Kanner G, Anderson G. Basic physics of the incandescent lamp (lightbulb). The Physics Teacher. 1999;37(9):520-525.

26. Song L, Connolly M, Fernández-Cruz ML, et al. Species-specific toxicity of copper nanoparticles among mammalian and piscine cell lines. Nanotoxicology. 2014;8(4):383-393.

27. Okada Y, Okajima H. Scavenging activity of furan derivatives against hydroxyl radical generated by fenton system. Yakugaku Zasshi. 1998; 118(6):226-230.

28. Li Y, Zhang W, Niu J, Chen Y. Mechanism of photogenerated reactive oxygen species and correlation with the antibacterial properties of engineered metal-oxide nanoparticles. ACS Nano. 2012;6(6):5164-5173.

29. Jose GP, Santra S, Mandal SK, Sengupta TK. Singlet oxygen mediated DNA degradation by copper nanoparticles: potential towards cytotoxic effect on cancer cells. J Nanobiotechnol. 2011;9:9.

30. Price M, Reiners JJ, Santiago AM, Kessel D. Monitoring singlet oxygen and hydroxyl radical formation with fluorescent probes during photodynamic therapy. Photochem Photobiol. 2009;85(5): 1177-1181.

31. Mohan R, Krishnamoorthy K, Kim S-J. Enhanced photocatalytic activity of Cu-doped ZnO nanorods. Solid State Commun. 2012;152(5): 375-380.

32. Wang M, Ren F, Cai G, Liu Y, Shen S, Guo L. Activating ZnO nanorod photoanodes in visible light by $\mathrm{Cu}$ ion implantation. Nano Res. 2014; 7(3):353-364.

33. Xing G, Xing G, Li M, et al. Charge transfer dynamics in $\mathrm{Cu}$-doped ZnO nanowires. Appl Phys Lett. 2011;98(10):102105-102103.

34. Huang MH, Wu Y, Feick H, Tran N, Weber E, Yang P. Catalytic growth of zinc oxide nanowires by vapor transport. Adv Mater. 2001;13(2): $113-116$.

35. Hatz S, Lambert JD, Ogilby PR. Measuring the lifetime of singlet oxygen in a single cell: addressing the issue of cell viability. Photochem Photobiol Sci. 2007;6(10):1106-1116.

36. Lin H-F, Liao S-C, Hung S-W. The de thermal plasma synthesis of $\mathrm{ZnO}$ nanoparticles for visible-light photocatalyst. Journal of Photochemistry and Photobiology A: Chemistry. 2005;174(1):82-87.

37. Greenwald RB. Poly(ethylene glycol) anticancer drug delivery systems. P R Health Sci J. 2002;21(2):113-121. 
38. Xia T, Kovochich M, Liong M, et al. Comparison of the mechanism of toxicity of zinc oxide and cerium oxide nanoparticles based on dissolution and oxidative stress properties. ACS Nano. 2008;2(10): 2121-2134.

39. Taveira SF, Lopez RFV. Topical administration of anticancer drugs for skin cancer treatment. In: Caterina AMLa Porta, editor. Skin CancersRisk Factors, Prevention and Therapy. Croatia: INTECH Open Access Publisher; 2011:247-272.

40. Allahverdiyev AM, Abamor ES, Bagirova M, et al. Anti-leishmanial effect of silver nanoparticles and their enhanced antiparasitic activity under ultraviolet light. Int J Nanomedicine. 2011;6:2705-2714.

41. Larsen EKU, Nielsen T, Wittenborn T, et al. Accumulation of magnetic iron oxide nanoparticles coated with variably sized polyethylene glycol in murine tumors. Nanoscale. 2012;4(7):2352-2361.

42. Mroz P, Yaroslavsky A, Kharkwal GB, Hamblin MR. Cell death pathways in Photodynamic therapy of cancer. Cancers. 2011;3(2):2516-2539.
43. Carpenter AE, Jones TR, Lamprecht MR, et al. CellProfiler: image analysis software for identifying and quantifying cell phenotypes. Genome Biol. 2006;7(10):R100.

44. Ribble D, Goldstein NB, Norris DA, Shellman YG. A simple technique for quantifying apoptosis in 96-well plates. BMC Biotechnol. 2005; 5(1): 12 .

45. Jimenez-Ruiz A, Alzate JF, MacLeod ET, Luder C, Fasel N, Hurd H. Apoptotic markers in protozoan parasites. Parasit Vectors. 2010;3: 104.

46. Savill J, Fadok V. Corpse clearance defines the meaning of cell death. Nature. 2000;407(6805):784-788.

47. Bakalova R, Ohba H, Zhelev Z, Ishikawa M, Baba Y. Quantum dots as photosensitizers? Nat Biotechnol. 2004;22(11):1360-1361.
International Journal of Nanomedicine

\section{Publish your work in this journal}

The International Journal of Nanomedicine is an international, peerreviewed journal focusing on the application of nanotechnology in diagnostics, therapeutics, and drug delivery systems throughout the biomedical field. This journal is indexed on PubMed Central, MedLine, CAS, SciSearch $®$, Current Contents $® /$ Clinical Medicine,

\section{Dovepress}

Journal Citation Reports/Science Edition, EMBase, Scopus and the Elsevier Bibliographic databases. The manuscript management system is completely online and includes a very quick and fair peer-review system, which is all easy to use. Visit http://www.dovepress.com/ testimonials.php to read real quotes from published authors.

Submit your manuscript here: http://www.dovepress.com/international-journal-of-nanomedicine-journal 